\title{
Dicção individual e intervenção pública em "Três sonetos positivos" de Joaquim Cardozo
}

\author{
Individual diction and public intervention in "Three positive sonnets" by Joaquim Cardozo
}

\author{
Everton Barbosa Correia \\ Universidade do Estado do Rio de Janeiro, Rio de janeiro, Rio de Janeiro, Brasil
}

$$
\diamond
$$

Resumo: Devido ao lugar impreciso que Joaquim Cardozo ocupa na historiografia literária brasileira, a exploração de sua obra aqui estará circunscrita ao raio de alcance de uma possível expressão individual, recortada em três sonetos qualificados pelo mesmo adjetivo:"positivos". Com isso, a positividade da qualificação textual deverá se converter em especulação sobre o sentido construído circunstancialmente naquela composição, que é tripartida e se desdobra na reflexão sobre o vocabulário do autor, notadamente pela utilização modalizada do adjetivo. Assim, os três sonetos serão considerados como instrumentos de acesso ao estilo do autor através do léxico utilizado. O soneto seria, pois, o cenáculo através do qual se materializa uma expressividade singular, mais facilmente identificável pelos limites da forma fixa, mas que deverá sinalizar algo da sua obra como um todo, onde o ritmo, a métrica, o vocabulário e o fraseado dos seus versos adquirem outros contornos, já que sofrem interferência de outras condicionantes. Óbvio está que a utilização da forma fixa por Cardozo desestabiliza o sentido do próprio soneto, vincando-se a seu modo na tradição.

Palavras-chave: Joaquim Cardozo; Poesia brasileira moderna; Soneto; Adjetivo; Estilo

\begin{abstract}
Due to inaccurate place that Joaquim Cardozo occupies in Brazilian literary historiography, the appreciation of his work here will be limited to the range of possible individual expression, cut in three sonnets qualified by the same adjective: "positive". With that, the positivity of textual qualification should be converted into speculation about the sense circumstantially built in that composition, which is tripartite and unfolds in the reflection on the vocabulary of the author, notably by the use of the adjective. Thus, the three sonnets will be considered as instruments of access to the style of the author through the lexicon used. The sonnet would be the upper room through which materializes a singular expressivity, more easily identifiable by the limits of fixed form, but that should signal something of his work as a whole, where rhythm, metric, the vocabulary and the phrasing of his verses gain other outlines, already suffering interference from the other conditions. Obviously the use of fixed form by Cardozo destabilizes the sense of own sonnet, creasing on his way in the tradition.
\end{abstract}

Keywords: Joaquim Cardozo; Brazilian Modern Poetry; Sonnet; Adjective; Style 
A maneira mais espontânea de aferir o reconhecimento autoral passa pela averiguação de quantas das suas frases ficaram gravadas na memória dos leitores ou quantos de seus títulos são identificados pelo público médio ou pelo leitor ideal, como se queira. Tal exercício traz consigo a compreensão de que reconhecer um autor implica ver na sua obra o que foi assimilado como um bem comum, tornado acessível. O trânsito entre a formalização artística e o uso cotidiano, na verdade, revelaria algo mais fundo, a saber, a existência de um vínculo dinâmico entre a expressão individual e sua conversão em objeto público, à proporção que a convenção social - incluindo aí a linguística - também alimenta o repertório individual de sujeitos, reconhecíveis como artistas ou portadores de interesse público. Sem ignorar que a dimensão autoral também inflecte sobre a convenção e que o público não é uma entidade abstrata, conviria especular algo acerca da legitimação do discurso literário, para a qual concorre vivamente a impressão dos interlocutores e dos críticos do autor, entre os quais se poderia requerer a opinião de um Manuel Bandeira ou um Carlos Drummond de Andrade, por exemplo.

Pois quando pensamos em desempenho verbal, é necessário fazer um paralelo entre a fala e a escrita como correspondência possível da conversão da esfera privada para a pública, deixando claro que tal correspondência não é simétrica à repercussão da obra e tampouco é linear na historiografia literária, mas pode servir de índice para o acompanhamento da recepção de um determinado autor em momento de sua publicação ou de outro evento literário, que fez dele um objeto de culto. Sem antecipar a demonstração, a hipótese ao menos pode impulsionar alguma reflexão produtiva: a fala que demanda uma voz, circunstanciada no tempo e no espaço, adquire, por seu turno, valor histórico e representativo justamente devido à sua particularidade. Se isso vale para considerar a autoria, haverá de valer também para os seus leitores, notadamente os especializados que se insurgem como críticos ou se solidarizam como interlocutores. Conforme seja, a fala objetivada por alguma demanda cotidiana produz certo efeito imediato, que, visto à distância adquire outro contorno, o que também vale para autores, interlocutores e leitores especializados. Porque outro é o efeito quando dispomos da linguagem revestida por algum tipo de formalização, que prevê interferência subjetiva. De acordo com o exposto, a linguagem objetiva adquire outra dimensão quando distanciada no tempo, ao passo que a linguagem subjetivada por algum princípio de formalização toma outra feição quando o distanciamento nos impõe outra valoração para a forma. O silogismo interessa, para que possamos fazer um uso produtivo da forma fixa, com vistas à expressão individual de Joaquim Cardozo, cuja voz será captada de um pronunciamento seu em circunstância pública, para confronto com o desempenho estilístico que se quer um correspondente de seu timbre individual no soneto.

A demonstração de tal hipótese ficará a cargo da intervenção pública de Joaquim Cardozo, tanto referencial quanto artisticamente, pela suposição de que pode haver um vínculo entre falas do mesmo sujeito em circunstâncias distintas, de onde se depreende a existência de uma voz particular. De acordo com tal hipótese, mais do que identificar um timbre individual, interessa visualizar a repercussão de uma circunstância precisa na expressão autoral, para a qual a referência se constitui também um índice de formalização. Por outra, a pauta está dada pela especulação do modo como um discurso proferido em circunstância pública e convertido em texto enseja uma compreensão que adquire valor representativo da fala e da expressão, histórica e subjetivamente. Nem tanto pela importância da fala em si, mas muito mais pela capacidade de absorver os conflitos no seu entorno, os quais, cristalizados em linguagem, podem se converter em expressão artística, porquanto aparecem formalizados em códigos legíveis pela convenção que se atualiza no uso que ele faz do soneto.

De saída, tomaremos como primeira circunstância textual o discurso do engenheiro Joaquim Cardozo na condição de paraninfo da turma de engenharia da Universidade de Pernambuco (UPE) que se formara nos idos de 1939. Circunstância essa que terá como contraponto formal o desempenho vocabular do autor em três sonetos, articulados entre si, constituindo uma composição tripartida, cuja enunciação não tem uma referência precisa. Então se configura um jogo em que a referência serve de índice para a expressão artística, necessariamente ambígua e impregnada de elementos subjetivos, que, sem aludir àquela referência, sofrem sua interferência como contingência estilística ou limitador expressional. Portanto, a referência se constitui como limitação expressiva, sem a qual o autor não impostaria sua voz como uma individualidade marcada objetivamente pelas experiências mundanas, repercutidas na sua formalização, cujo índice primeiro vem a ser o vocabulário. Sim, porque interessa menos aferir milimetricamente os pontos de articulação entre uma e outra modalidade discursiva, do que vislumbrar algum grau de interferência aí, não necessariamente positiva, já que estamos movidos pela interdição, mas certamente produtiva, uma vez que impulsiona a reflexão aventada. A apreciação do texto literário esbarraria, pois, inapelavelmente no limite formal que esconde e cala interdições através do que quer que entendamos como forma literária, seja a realização linguística circunstanciada historicamente ou o artefato estético limitado a dada cultura.

Ocorre que tal percurso de leitura adquire dimensão exponencial quando pensamos na figura espectral de 
Joaquim Cardozo, a um só tempo engenheiro e poeta, capaz de fundir o máximo de objetividade com uma subjetividade escorregadia como realização textual concreta, no mesmo passo em que reúne elementos de referencialização e ficcionalização da linguagem. Não pela abstração de que há uma unidade indivisível na expressão de um autor em momentos separados e desvinculados entre si, mas como expedientes expressionais que o caracterizam intimamente e que convergem para sua dimensão mais pública, sem se contradizer e sem se dividir como virtualidades do sujeito, mas como sua potencialidade expressiva. Consoante o raciocínio, o efeito limitante da circunstância passaria a ser o índice de revelação da sua objetivação expressional pública. Dito de outro modo, o autor se faz objeto público e circulante porque houve algo na esfera privada que limitou sua expressão, que vibra na interdição que o impulsiona.

A pretexto de rastrear o percurso autoral, pautado pelo desempenho na escrita, seja referencial ou poética, tomaremos os "Três sonetos positivos" como contraponto ao discurso de paraninfo de formatura, que articulados entre si servirão de recorte metodológico para a exploração lexical do autor, por meio da qual poderíamos visualizar talvez um estilo como a cristalização da voz que incorpora o seu entorno e o converte em atributo expressional, ainda que sob interdição. Com o propósito de circunscrever o horizonte vocabular, ficaremos com a classe de palavra que talvez seja mais controvertida na pena do poeta e que aponta para a melhor atribuição de sentido, porque ali é objeto de um uso imprevisto, inusitado e expansivo do entendimento da linguagem, radicado mais na sua função do que na descrição gramatical, como se contradissesse a abstração classificatória da linguagem pelo uso que Joaquim Cardozo faz do adjetivo. Constitui-se, por conseguinte, uma identidade possível entre o poeta e o uso que ele faz do adjetivo, que passa a ser índice de sua expressão e traço de seu estilo, circunstancialmente ambientados no soneto. Fiquemos, por ora, com a parte do discurso de paraninfo da turma de engenharia da UPE (Universidade de Pernambuco) formada em 1939, que melhor ilustra o desempenho verbal do autor e que circunstancialmente mais nos interessa.

Sei bem que a vossa preparação prática é a parte mais limitada de vossos conhecimentos, não apenas pela falta entre nós desses laboratórios modernos e adequados, mas também pelo desinteresse, pela falta de entusiasmo dos administradores e empreendedores de serviço, entre os quais muitos engenheiros que se satisfazem com a realização de obras medíocres, provisórias e precárias, numa falsa compreensão de economia. Para terdes uma ideia clara do que afirmo, observai os trabalhos de engenharia que há vários anos se vem realizando em Pernambuco, se fizerdes um gráfico de nossas estradas verificareis que os revestimentos não correspondem ao diagrama do tráfego; passamos bruscamente pelas áreas calçadas das cidades para as estradas de terra, como se não existisse possibilidade de uma graduação nos revestimentos das rodovias. Quanto às pontes e aos edifícios, as primeiras nunca obedeceram a qualquer classificação, os segundos não possuem uma disposição orgânica definida, construímos um edifício para uma escola superior de Agricultura e depois adaptamos a uma colônia de alienados; edificamos um reformatório para menores e depois transformamos em escola de Agronomia, o que nos faz admitir sem escândalo a transformação de amanhã de uma cadeia em grupo escolar, ou de uma igreja em açougue (CARDOZO, 2009, p. 61).

Afora os envoltórios que constituem o protocolo da ocasião, animada por formandos ávidos pelo mercado de trabalho, o discurso se pauta na íntegra pela advertência do que se espera dos profissionais do ofício, para quem a tarefa de servir ao bem comum não raro implica se confrontar com o poder público constituído. Tomado laboratório expressional, o exemplário exposto no discurso opõe alguns substantivos que indicam construções incompatíveis entre si, a exemplo de "escola superior" e "colônia de alienados", "reformatório" e "escola", ou "cadeia" e "grupo escolar", e mais ainda, "igreja" e "açougue". Tudo isso se constitui como correlatos verbais para indicar a prática das políticas públicas, ou ainda, quais os expedientes utilizados pela governança pública para configurar o espaço urbano, onde se daria a experiência de sociabilização para a qual a oposição entre prédios com funções tão díspares parece natural. Se esta aparente naturalidade serve para descrever a prática governamental, não é no mesmo tom que o autor utiliza quando se volta para a descrição do espaço público, quer se refira a estradas ou pontes, porque aí os pares opositivos obedecem a outra conotação descritiva, donde podemos destacar os seguintes enunciados: "os revestimentos não correspondem ao diagrama do tráfego", "passamos bruscamente pelas áreas calçadas das cidades para as estradas de terra", " [pontes] nunca obedeceram a qualquer classificação", ou ainda, "[edifícios] não possuem uma disposição orgânica definida". A síntese das oposições pode ser feita assim: quando o autor se volta para a descrição do espaço público a oposição lexical denota a precariedade das construções submetidas à governança; quando na mesma frase o autor se volta para a intervenção governamental no espaço público a oposição lexical adquire uma conotação fina, porquanto opera uma descrição grotesca dos prédios públicos, sem diferençar açougue e igreja, para ficar no último par opositivo.

Não custa lembrar que nos idos de 1939, quando o discurso foi proferido e tornado público, o Governo do Estado de Pernambuco estava a cargo do interventor 
federal Agamenon Magalhães, assim constituído por Getúlio Vargas como fizera com todos os demais estados da federação. Por outro lado, a Universidade de Pernambuco como as demais universidades do país tinham administração atrelada à governança estadual, posto que ainda não estivessem sob a tutela do governo federal. Portanto, havia certa ingerência no espaço público restrita a determinações locais, justificáveis por si sem a mediação de quaisquer instâncias exteriores, uma vez que em regimes de exceção qualquer manifestação de poder se basta, independente até do critério de sua exposição. Diante do quadro, é de se presumir que não faltassem interessados a levar de bandeja o discurso de Joaquim Cardozo feito em circunstância pública, mas de interesse restrito, sem jamais ter o poder de ameaçar poderes constituídos. Apesar de bastante sofisticada, a realização discursiva de Joaquim Cardozo lhe custou bastante caro, a considerar que poucos dias depois de seu pronunciamento foi chamado a depor em delegacia, cujo desfecho resultou no seu afastamento de sua cidade natal, sob a alegação de que sua atuação comprometia o livre exercício do serviço público, conforme foi publicado no Diário Oficial do Estado de Pernambuco em 28 de dezembro de 1939, de acordo com a subscrição abaixo, que reproduz inclusive o número do ato de sua exoneração do serviço público.

Ato $\mathrm{n}^{\mathrm{O}}$ 1472, de 28 de Dezembro de 1939/ O Interventor Federal no Estado, tendo em vista o ofício do engenheiro Joaquim Cardoso, encaminhado pelo Secretário de Viação e Obras Públicas, resolve exonerálo a bem do serviço público do cargo de Engenheiro Auxiliar da Diretoria de Viação de Obras Públicas e Oficinas, por incapacidade técnica para o exercício das funções, confessada naquele documento de próprio punho (Diário Oficial do Estado de Pernambuco, 1939, p. 5).

Não deixa de ser curioso que a publicação faça remissão a outro documento redigido a próprio punho no qual o engenheiro teria confessado sua incapacidade técnica. A informação salta aos olhos porque o suposto réu confesso havia sido convidado para ser paraninfo da turma justamente devido a suas habilidades técnicas, uma vez que os torneios retóricos do palestrante, por mais ilustre que fosse e não era o caso, talvez não despertassem tanto interesse a uma turma de engenharia da primeira metade do século XX brasileiro. Acresce a isso que o mesmo inepto confessado a próprio punho viesse a ser, logo em seguida, o engenheiro escolhido por Oscar Niemeyer para colocar Brasília em pé, já que sua relação com os engenheiros não podia ser pacífica, haja vista a relutância dos profissionais em fazer cálculos que dessem sustentação a suas curvas. Ficou a cargo de Joaquim Cardozo o estabelecimento de regras e equações compatíveis com as projeções do arquiteto que ficou reconhecido pelas suas excentricidades, mas que não teriam o mesmo alcance sem a estruturação do engenheiro civil de que teve de se valer. $\mathrm{O}$ interessante é que tenha sido este mesmo sujeito a confessar incapacidade técnica para o exercício das suas funções. Tal informação importa não somente porque esclarece o motivo de Joaquim Cardozo ter deixado o Recife em direção ao Rio de Janeiro, onde estava sediada a capital federal, mas sobretudo porque o episódio parece ter se gravado fundo na sensibilidade que repercute na sua expressão. Expressão essa que aqui ficará circunscrita a uma meia dúzia de adjetivos gravados em três de seus sonetos que articulam uma mesma composição.

A razão de tal escolha não é tão arbitrária nem tão extemporânea quanto parece, pois sendo o soneto uma forma cristalizada no medievo, não deixa de ser curiosa a sua repercussão na literatura moderna, a considerar a quantidade de colaborações poéticas presentes na tradição luso-brasileira constituída desde a época colonial. A considerar o poder expressivo que essa forma fixa traz consigo, a ponto de se confundir com a própria ideia de poesia, seu poder de revelação será aqui testado menos pelo que ali se guarda da tradição ocidental, do que pelo que se deslinda de traço distintivo da escritura de um autor, inscrito de maneira turva na modernidade brasileira. Por isso, a apreciação dos sonetos de Joaquim Cardozo como hipótese de leitura tem alguns ancoradouros que se amarram: 1 - seus sonetos foram escritos em momento que a forma fixa tinha grande voga no contexto brasileiro, a ponto de poetas importantes intitularem suas respectivas publicações sob o título de Livro de Sonetos, tal como o fizeram Jorge de Lima e Vinícius de Morais, ou Murilo Mendes com Sonetos brancos, afora a quantidade inumerável de sonetos publicados naquele momento; 2 - Joaquim Cardozo somente foi considerado como sonetista na antologia Forma e expressão do soneto, organizada por Paulo Mendes Campos (1952), com a ilustração de apenas um dos três sonetos que vieram a constituir outra composição tripartida que é "A aparição da rosa"; 3 - os seus leitores sempre deram atenção a outras partes e a outros aspectos de sua produção, sem relacionálas com aquela forma fixa. A exploração ensaiada aqui traz consigo a interferência de seus leitores, impulsionada da apresentação de sua obra pelas editoras que, por sua vez, criam motivações no público consumidor sob o aparato do mercado editorial, dos estudos literários ou do ensino de língua. A partir daí, a obra pode se tornar objeto de valorização de acordo com os estímulos sociais que absorve ou suscita, entre os quais não podemos ignorar o papel exercido pela escola, do ensino básico ao superior.

Diante disso, soa bastante curioso que a obra de Joaquim Cardozo não tenha despertado grande interesse nos leitores em geral, apesar dos usos a que ela poderia 
se conformar, já que oscila entre múltiplas tendências da poesia à prosa ficcional ou ensaística, passando pelo teatro, como se ao longo de sua produção não houvesse nada que já não estivesse grafado no seu livro primeiro. Livro este já de si demasiado complexo e, talvez por isso, dê a entender que suas composições subsequentes devessem adquirir valor secundário na caracterização do perfil literário do autor e, com isso, estabelecer um vínculo íntimo e insondável entre a publicação de estreia sob o título de Poemas (1947) - onde não constavam sonetos e tudo o mais que veio a ser publicado posteriormente sob sua autoria, incluindo aí sua Poesia completa e prosa (2007). Conforme o raciocínio, os sessenta anos que separam estas duas publicações não foram suficientes para expandir o perfil de poeta cristalizado em meados do século XX, fosse pelo número exíguo de trabalhos acadêmicos sobre aquela obra, pela escassez de edições com o nome do autor ou pela designação nas histórias literárias e sua compulsiva ausência dos livros didáticos.

Feita a constatação, cumpre dizer que o seu lugar na historiografia literária sempre foi nebuloso e esfumado continua a ser, o que só estimula sua apreciação como um todo, que aqui estará figurativamente ilustrada pelos seus sonetos, ainda que se trate de uma parte esparsa e ocasional no conjunto de sua escritura. Devido à inquietação para encontrar naquela obra uma parte que dimensionasse sua totalidade, achei por bem apresentar os "Três sonetos positivos" de Joaquim Cardozo, publicados no livro Signo estrelado (1960). Este é o segundo livro do autor tardio - que só teve um livro de autoria exclusiva aos cinquenta anos - e quando Manuel Bandeira organizou a publicação que veio a ser sua primeira aparição em livro foi numa coletânea que, a pretexto de abrigar autores arredios e sinuosos como o pernambucano, recebeu o título de Antologia de poetas brasileiros bissextos contemporâneos (1946), cuja caracterização é bastante controversa, como se vê:

Poeta bissexto deve, pois, chamar-se aquele em cuja vida o poema acontece como o dia 29 de fevereiro no ano civil. Esquematização grosseira. Em suma, bissexto é todo poeta que só entra em estado de graça de raro em raro. [...] Bissexto é um Aníbal Machado, escritor esporádico, em quem o verso é uma espécie de estado de graça que assoma entre largos períodos de sombra; um Dante Milano, notável pela unidade de sua forma poética, de grande pureza; um Joaquim Cardozo, cuja produção se recusa à intimidade dos que the são mais chegados, tão íntima quer ser (BANDEIRA, 1946, p. 5-6).

Ao assumir o caráter redutor da esquematização, o organizador do volume está anunciando, de antemão, sua insuficiência que se explicita no seu exemplário.
Pois se a condição bissexta se aplica exemplarmente a Aníbal Machado, não produz o mesmo efeito quando se volta para Dante Milano ou Joaquim Cardozo, que ali estão reunidos pela excelência de sua expressividade poética, sem que tivessem se tornado poetas conhecidos pelo público em larga escala. Aquela seria, portanto, a oportunidade para deixar em circulação alguns dos poemas contemporâneos prediletos a Manuel Bandeira, que não se conformavam a uma classificação precisa nem tinham sido publicados em livro até então. Note-se que curiosamente Joaquim Cardozo ali figura como aquele a quem os mais chegados não podem acessar na intimidade da produção, muito embora ela se queira íntima, aliás justo por isso. A curiosidade tanto mais se aguça quanto mais especularmos acerca de uma intimidade desejada em versos e em versos inacessível. Tal contradição não deixa de chamar a atenção para o perfil tão paradoxal de uma poesia que se quer clara e comunicativa. $\mathrm{O}$ convite à leitura daquela poesia, segundo o prefaciador do volume, parece demandar um acompanhamento circular, que não se esgota e ao qual ela não se conforma, porque se recusa a credenciamentos prévios. Tanto é verdade que, na segunda edição do volume, Joaquim Cardozo não foi arrolado mais entre os bissextos, porque entre as duas décadas que separam uma edição da outra, o poeta arredio a publicações teve vários livros editados, conforme o próprio organizador informa no novo prefácio da coleção, que fora alterada.

Voltei com vivo prazer a me ocupar dos meus bissextos. Mas com vivo pesar também, pois logo vi que teria que desfalcar o livro de dois grandes poetas que, como boxeadores que mudam de categoria, passaram de bissextos a contumazes, publicaram vários livros e hoje figuram em todas as antologias. São eles Joaquim Cardozo e Paulo Mendes Campos (BANDEIRA, 1964, p. 110).

A mudança de categoria, que não raro depõe a favor dos boxeadores, não serviu para desanuviar o perfil de Joaquim Cardozo, ao menos se for visualizado restrospectivamente pela crítica literária brasileira que ainda não dispôs de uma chave de leitura que lhe pareça remediavelmente adequada. Talvez daí advenha certa estranheza na sua recepção, cujo correlato mais evidente seja a evasiva na sua elucidação e sua consequente imprecisão no contexto historiográfico. O comentário se impõe pela necessidade de dissipar possíveis malentendidos na caracterização de Joaquim Cardozo feita por Manuel Bandeira, como se os dois fossem partidários de agremiações literárias distintas, quando, na verdade, havia entre eles uma simpatia mútua e irreprimível, registrada desde os idos de 1925, quando da publicação do Livro do Nordeste (FREYRE, 1979), onde Bandeira publicou pela 
primeira vez o poema "Evocação do Recife" e Joaquim Cardozo figura como crítico da poesia bandeiriana com o artigo intitulado "Um poeta pernambucano: Manuel Bandeira".

O livro Poemas de Joaquim Cardozo só foi publicado em 1947, por ocasião da celebração dos seus cinquenta anos, sob instâncias de seus amigos Bandeira, Drummond e Cabral, que contribuíram com a publicação, organizada por Eustáquio Duarte e Meyer Faimbaum. É bem verdade que, mesmo sem ter sido timbrado em livro, o poeta Cardozo contribuiu subterraneamente para a constituição de nossa tradição moderna, não só pela impressão que causava nos seus leitores especializados majoritariamente poetas -, cuja simpatia era engatilhada automaticamente, a exemplo do que assinala Carlos Drummond de Andrade já naquele primeiro momento de sua publicação, na condição de prefaciador daquele volume.

\begin{abstract}
A poesia modernista foi, em grande parte, uma poesia de região, de município e até de povoado, que se atribuiu a missão de redescobrir o Brasil, considerando-o antes encoberto do que revelado pela tradição literária de cunho europeu. [...] Mas esse excesso de Brasil corria o risco de degenerar simplesmente em excesso de pitoresco. De tal modo o particular se substituía ao geral, na sofreguidão dos revolucionários, marcados ainda por uma tendência pulverizadora ao humorismo. Inclinado à solidão pelas exigências do temperamento, Joaquim Cardozo foi, porém, modernista mais ausente do que participante. Se refletiu as inquietações de época e de grupo, fê-lo sem a passividade que em outros poetas daquela fase excluiria qualquer reivindicação do indivíduo. Um aparelho severo de pudor, timidez e auto-crítica salvou-o das demasias próprias de todo o período de renovação literária (ANDRADE, 1947, p. 7-8).
\end{abstract}

Vale lembrar que a maioria da crítica feita à obra de Joaquim Cardozo nunca ultrapassou o limite da glosa a estas considerações de Carlos Drummond de Andrade - seja reforçando o vetor que aponta para seu modernismo regionalista ou seu modernismo ausente -, com exceção talvez de Antonio Houaiss (1968), de Fernando Py (1984) e de José Guilherme Merquior (1996). Ao chamar a atenção para uma tendência crítica de se repetir narcisicamente a si mesma, não existe aqui a intenção de puxar a leitura do poeta para o outro lado. Ao invés, sem fugir muito à regra, já confirmada em outro artigo "Joaquim Cardozo, leitor de Manuel Bandeira" (CORREIA, 2010), o foco da leitura será deslocado para certo aspecto daquela frase de Drummond, quando destaca em Joaquim Cardozo um aparelho de rigor e autocrítica, o qual tentarei decifrar através da apreciação dos "Três sonetos positivos". Antes disso, todavia, convém lembrar que o prefaciador Drummond está se referindo a uma coletânea de 43 poemas publicados no espaço de 22 anos e que, pela própria materialidade da produção cardoziana, reforça a caracterização bissexta de Bandeira, feita no ano anterior à publicação do livro Poemas, prefaciado pelo itabirano. Aliás, Joaquim Cardozo parece ter tomado gosto pela publicidade a partir daí, haja vista que seu livro seguinte teve lapso temporal de 13 anos, sendo de 1960, portanto com o espaçamento de nove anos a menos do que a publicação primeira do seu poema "Alvarengas" e sua timbragem em livro. Para quem demorou 22 anos para o primeiro livro, demorar 13 para o segundo parece até uma conquista. Deve-se assinalar também que nesta segunda publicação há uma quantidade maior de poemas e uma diversidade maior de assuntos e formas a serem abordados pelo poeta, a exemplo dos sonetos de que nos ocuparemos.

Para efeito de análise, a obra cardoziana aqui ficou circunscrita a três sonetos no universo de pouco mais de três dezenas, distribuídas ao longo daquela obra, da qual 10 (dez) sonetos foram publicados no livro Signo estrelado. O que animou a escolha dos "Três sonetos positivos" foi a incidência dos adjetivos de modo diverso, mas que possibilitavam a compreensão de uma utilização mais ampla da classe gramatical por parte do autor, sem restringi-la a uma ocorrência específica e demonstrando como tal utilização se faz sistêmica na expressão de Joaquim Cardozo, quer pensemos uma composição específica ou a obra como um todo. Aquilo que eventualmente venha parecer inusual em cada um daqueles sonetos acaba por conferir um efeito de síntese na escritura cardoziana. Nem tanto por consignarem algo que se queira como estilo do autor e tampouco por lhe agregarem ao espírito de uma época ou de determinado movimento literário, mas muito mais pelo que revelam da utilização do adjetivo por um autor específico, que amplia o entendimento da forma fixa utilizada na língua portuguesa, bem como as miudezas linguísticas que encerram uma expressão, que, por sua vez, passa a ser representativa de um lugar e de um tempo, circunstancialmente dele e extensivamente nossos, como se vê.

\section{Três sonetos positivos}

I

Eu te direi de amor em frase nova:

Verbo que em si conduz as singulares

Emanações fatais da escura prova

Que é força de ambições crepusculares.

$\operatorname{ER}(6-10)$

ER (6-10)

ER (4-8-10)

$\mathrm{ER}(6-10)$

Eu te direi da flor que se renova

$\operatorname{ER}(6-10)$

Em frondes de segredos seculares,

ER(6-10)

Surgindo da clausura de uma cova

$\operatorname{ER}(6-10)$

Em mutações tranquilas e lunares. 
Direi também de folhas, de aventuras

Levadas velozmente nas alturas

$\operatorname{ER}(6-10)$

$\operatorname{ER}(6-10)$

$\operatorname{ER}(6-10)$

Dos ventos e das asas vencedoras:

Mas de tanto dizer fique o silêncio

Que é cinza de palavras e que vence

$\operatorname{ER}(6-10)$

ER(6-10)

O surto de inverdades tentadoras.

ER(6-10)

\section{II}

Por senda escura uma visão me leva...

Em vez dos claros rumos da manhã

$\mathrm{ER}(4-8-10)$

Sigo um caminho, um chão feito de treva,

De légua, de colina e de rechã.

$\operatorname{ER}(6-10)$

$\operatorname{ER}(6-10)$

$\operatorname{ER}(6-10)$

Em vez do alvor das nuvens que me enleva, ER(6-10)

Das nuvens de que a tarde é tecelã

$\operatorname{ER}(6-10)$

Olho o vulto da noite que se eleva,

$\operatorname{ER}(6-10)$

Ouço o vento do mar na telha-vã.

$\mathrm{ER}(6-10)$

Da noite preta que me estende os ubres ER(4-8-10)

De onde sorvo os meus sonhos insalubres ER(6-10)

E o leite sugo de imprecisas mágoas

ER(4-8-10)

Do mar que ao fim de tudo há de me ter

Se o meu ferido corpo merecer

$\operatorname{ER}(6-10)$

$\operatorname{ER}(6-10)$

O encerro, o encanto e cântico das águas.

$\operatorname{ER}(6-10)$

\section{III}

Sobre o meu coração dedos de luvas, Dedos sutis de mãos consoladoras,

Roçaram leves num roçar de chuvas

De vento e de verão sobre lavouras.

$\operatorname{ER}(6-10)$

ER(6-10)

ER(4-8-10)

$\mathrm{ER}(6-10)$

Mas se um vinho mortal de eternas uvas

A embriaguez me trouxe, e, aterradoras,

Fulgurações de rútilas saúvas

ER(6-10)

$\operatorname{ER}(6-10)$

$\operatorname{ER}(6-10)$

ER(6-10)

As tuas mãos lacustres me envolveram,

E de águas matinais frescor me deram...

Mãos e que mãos tão lúbricas e brandas!

$\operatorname{ER}(6-10)$

$\operatorname{ER}(6-10)$

$\mathrm{ER}(6-10)$

As cores das manhãs que me inundaram

Enfim bruma e fantasmas dispersaram

$\operatorname{ER}(6-10)$

$\operatorname{ER}(6-10)$

$\mathrm{ER}(6-10)$

De noites brancas, lívidas, nefandas.

(CARDOZO, 2007).

De imediato chama a atenção a regularidade formal que anima os três sonetos, tanto no aspecto rímico, constituído de rimas alternadas nos quartetos e emparelhadas nos tercetos, quanto no aspecto métrico cuja incidência do decassílabo heróico se faz uma constante, só contrabalançado por ocorrências acidentais do sáfico, sendo 1 (uma) no primeiro e outra no terceiro sonetos e 3 (três) no soneto intermediário. A informação vem a calhar porque tal regularidade na forma pode ser lida como um índice da positividade que adjetiva a trinca de sonetos. Tal positividade da forma é contradita pelo sentido depreendido da referencialidade dos versos, que trazem consigo enunciados aterradores, tais como: no soneto
I - "Mas de tanto dizer fique o silêncio/ Que é cinza de palavras e que vence/ O surto de inverdades tentadoras"; no soneto II - "Da noite preta que me estende os ubres/ De onde sorvo os meus sonhos insalubres/ E o leite sugo de imprecisas mágoas"; no soneto III - "As cores das manhãs que me inundaram/ Enfim bruma e fantasmas dispersaram/ De noites brancas, lívidas, nefandas". Os três tercetos recortados de cada um dos sonetos menos do que sintetizar o sentido expresso ao longo da composição tríptica - suportando uma narrativa intrincada e ambígua, como é próprio a todo poema e que se aguça aqui -, revela uma contradição intransponível entre o que é anunciado pela forma e o que se realiza no interior do poema, porque se faz incontornável, uma vez que lhe é constitutiva nos seus interstícios. Com o propósito de preencher a lacuna existente entre a forma facilmente identificada do soneto e sua forma interiorizada no vocabulário, tomaremos o adjetivo como classe gramatical materializada na linguagem e utilizada como um significante possível, que enlaça o interior do poema e sua formalização exteriorizada na rima e na métrica.

Os adjetivos do poema que rimam entre si são os seguintes: soneto I - singulares e crepusculares, seculares e lunares, vencedoras e tentadoras; soneto II - tecelã e vã; soneto III - consoladoras/ aterradoras e salvadoras, brandas e nefandas. Além do campo semântico que se constitui de adjetivo para adjetivo, é preciso reconhecer tal campo semântico expandido nas rimas entre adjetivo e locução adjetiva, enlaçando não só as palavras da mesma classe gramatical, mas também aquelas que exercem a mesma função na linguagem, levando a crer que a classificação gramatical é extensiva à função que as palavras exercem no interior do discurso, passando a constituir seu sentido, não mais restrito à referência convencionada - seja gramatical ou da forma literária -, mas expandindo o sentido do poema através das combinações das palavras que contemplam outros planos de significação para além convenção estabelecida. A partir daí se oferece também a possibilidade de constituir um campo semântico específico pela relação do adjetivo com a locução adjetiva, pela relação de locução adjetiva para locução adjetiva e pela relação da locução adjetiva com o substantivo, como constitutivos de múltiplos sentidos extraídos da função que o nome exerce ali, como se segue: soneto I - nova/prova e de cova; soneto II - de manhã e de rechã; soneto III - de luvas e de chuvas, de chuvas e uvas, de chuvas e saúvas.

Assim, as palavras passam a significar mais pela função exercida no interior do discurso do que pela classificação que prevê certa funcionalidade. Ao prever novas funções para as palavras, a classificação se expande e, por extensão, os significados depurados do jogo de combinações também. Sob tal perspectiva, podemos 
chegar a outra maneira de substantivar o adjetivo ou adjetivar o substantivo, procedimento característico a Joaquim Cardozo já assinalado pela crítica (PY, 1984), porque presente na sua produção desde seu primeiro momento, quando identificamos expressões como: "azul céu" por "azul celeste", ou ainda, "ar silêncio" por "ar silencioso". Tal associação só se torna possível porque o autor cinde, dilapida e reelabora a função gramatical das palavras no uso elástico e imprevisível do vocabulário. Tendo sido o autor publicado em jornais desde a década de 1920, seus princípios formais cravados na palavra viriam ressoar agudamente algumas décadas depois na obra de seu amigo e confrade João Cabral de Melo Neto, em várias extensões, a exemplo do título incômodo de sua obra mais conhecida, que é Morte e vida Severina (1956). Ao aplicar ao substantivo "Severina" uma função adjetiva, que se refere simultaneamente a "morte" e a "vida", João Cabral estaria repercutindo o mesmo procedimento inaugurado e explorado à exaustão pelo seu antecessor, fosse pela adjetivação do substantivo ou pela sua aplicação a vários vocábulos contíguos e simultâneos. Ao destacar o adjetivo como classe de palavra preferencialmente passível de apreciação naquela obra, estaríamos observando um procedimento que, de tão reincidente, se torna característico à expressão cardoziana e que, por isso, merece atenção especial, seja pela exploração propriamente linguística ou pelo modo como repercute na poesia que lhe é posterior, notadamente na de João Cabral.

A respeito das dobras e vincos da tradição literária brasileira do século XX, é preciso assinalar a utilização de recursos que se fizeram incisivos na nossa expressão da língua portuguesa. Aliás, é preciso reiterar que apesar de todas as transformações históricas e linguísticas pelas quais passaram as múltiplas tradições ocidentais, o soneto indiscutivelmente vigora como a forma fixa que melhor ilustra e representa a ideia de poesia que se cristalizou no Ocidente, seja no âmbito acadêmico ou no senso comum, e que repercute ainda nos nossos dias, como é bem sabido. O fato inquestionável é que o soneto foi capaz de passar do Medievo à Modernidade, acompanhando e incorporando os mais variados abalos registrados pelo decurso histórico e linguístico, sem deixar de atuar como um vetor considerável à expressão poética, a indicar os percalços trilhados pela convenção literária. Mesmo se considerarmos aqueles movimentos literários que se investiram do encargo de dar balanço à tradição, a exemplo do Romantismo ou do Modernismo, mesmo aí encontraremos explorações mais insólitas e agudas daquela forma fixa. Entre nós, basta lembrar de certo Gonçalves Dias ou certo Àlvares de Azevedo, no Romantismo; ou ainda, de certo Manuel Bandeira ou certo Guilherme de Almeida, no Modernismo.
Com isso, cumpre destacar que o soneto subsistiu na tradição literária ocidental, conquanto tenha sido capaz de absorver as demandas do plano social, histórico ou linguístico que se colocaram na ordem do dia. Portanto, se há algo de remoto que o soneto nos comunica residualmente - quer pensemos em Petrarca, Quevedo ou Camões -, por outro lado, esta forma se apresenta como o espaço próprio da poesia para registrar o que houve de mudança de mentalidade, de valores e de hábitos, sem abrir mão de seus contornos mais facilmente identificáveis, a saber, dois quartetos e dois tercetos, que se desdobram em rimas emparelhadas ou interpoladas e que, na tradição em que a língua portuguesa e a literatura brasileira se encontram, se compõe em decassílabos. Formato este em que Joaquim Cardozo exerce uma interferência significativa e permanente, porque podemos visualizar aí, seja como registro lingüístico ou invenção criativa, uma forte desestabilização e ampliação da língua portuguesa falada no Brasil.

Se tomarmos, pois, o soneto como este cenáculo através do qual podemos visualizar as contradições históricas e linguísticas, gravadas no plano literário, por conseguinte disporemos de algo que resguarda a tradição convencionada e se renova justamente a partir daquilo que foi estabelecido. Interessa, por isso, não apontar o que se conservou através do soneto, mas sobretudo o que se transforma naquela forma fixa que incorporou diversas disposições sintáticas, semânticas e lexicais, que, por sua vez, passam a ser índices das transformações sociais e históricas, que nos conduzem a um mergulho mais fundo naquilo que entendamos por forma e nos sentidos possíveis que possamos lhe atribuir. Segundo o raciocínio, convém que toda e qualquer consideração discursiva seja empreendida dos intestinos do texto analisado, de vez que o soneto, a despeito de todas as suas variações, nunca perdeu sua dimensão textual, donde a literatura se entrelaça e se encrava na língua, cuja sistematização haverá de passar necessariamente pelas classes gramaticais. Classes gramaticais que, materialmente, organizam e desestabilizam a forma do soneto, que, a rigor, é o que nos interessa: como o léxico do discurso interfere na sua formalização mais ampla? Como a forma fixa se atualiza através do uso do vocabulário? Mais ainda: como a utilização de uma classe de palavra pode adquirir representação social numa forma literária fixa?

Sem querer abordar todas as classes gramaticais de uma vez só, insurgimo-nos sobre o modo como o adjetivo se reveste e se desdobra em funções outras, ou ainda, como o substantivo se reveste de função adjetiva, seja quando compõe uma locução ou sofre interferência do adjetivo que o qualifica ou pelo adjetivo com que rima. $\mathrm{E}$ como o soneto foi a forma escolhida por ser, naturalmente, 
portadora de uma ambiguidade que conserva e altera a substância do discurso, a escolha do poeta se deu por igual motivo, haja vista que, tendo ele sido o precursor da substantivação do adjetivo - depois divulgada por João Cabral - é autor de uma quantidade de sonetos que permite a visualização do procedimento linguístico circunscrito àquela forma fixa que muito tem nos animado. Por outra, Joaquim Cardozo passa a ser o objeto da investigação por conta de sua habilidade com o verso, a ponto de estipular uma modalidade discursiva própria para sua expressão, quer pensemos na métrica, na rima ou na gramática utilizada, justamente porque interfere concretamente na utilização do léxico em movimento, porque não está engessado, consoante as evidências. Com isso, ele inova e instaura novos parâmetros para a utilização da língua, quer pensemos em advérbios ou substantivos condicionados pelos adjetivos, a exemplo do seu "Soneto somente".

Conforme o raciocínio, o qualificativo passa a ser a própria substância das coisas descritas nos poemas cardozianos, incluindo aí a subjetividade cindida e arredia do autor que não se conforma a regramentos ou convenções falsamente instituídas, mas testa as possibilidades do real no instrumento que lhe está acessível para sua expressão, que é a língua portuguesa com que travou contato. A aparência exterior e formal será tanto mais indicativa do referente descrito quanto mais absorver suas propriedades ou se descobrir como parte delas, sem fazer a distinção entre o objeto e sua caracterização, o que incidirá inapelavelmente sobre sua constituição mesma, sua constituição discursiva. A qualificação do objeto será tanto mais precisa quanto mais indicar a função que exerce no seu local de pronunciamento, o que amplia e, simultaneamente, desestabiliza o que quer que queiramos como contexto ou se apresente como real. Quero dizer, qualquer que seja a compreensão do contexto, haverá uma concessão a ser feita de seu entendimento pela desestabilização que a circunstância do soneto promove, não pelo que muda efetivamente no contexto - que, a rigor, se conserva -, e sim pela sua compreensão que será vaga e remotamente alterada no confronto direto com a nova experiência de leitura que o soneto cardoziano permite.

Adjetivos enquanto qualificativos interferem não só na substância das coisas a que Joaquim Cardozo se refere, mas também na disposição do tempo e do espaço, dada pela dimensão adverbial que passa a lhes absorver. No seu caso, a condição adjetiva vem a ser um correlato de sua condição de estar no mundo, ao menos enquanto objeto de linguagem. $\mathrm{O}$ adjetivo passa ser simultaneamente definidor da condição do objeto a que se refere e comporta (as referências do soneto e o soneto mesmo), bem como do sujeito que o constrói (Cardozo e seus leitores), sob perspectiva em movimento constante, o qual, por sua vez, vem a ser indicativo do aspecto que tal objeto passa a ter naquela circunstância de pronunciamento bem especificamente no poema. A materialidade da escrita passa, por seu turno, a embaçar e a desestabilizar a linguagem e sua representação social, revelando-a num plano mais fundo e às vezes tangível, ao menos na expressão de certo Joaquim, que tão próximo dos cardos ficou, Cardozo, como um signo estrelado.

\section{Referências}

ANDRADE, Carlos Drummond. Prefácio. In: CARDOZO, Joquim. Poemas. Rio de Janeiro: Agir, 1947. p. 7-13.

BANDEIRA, Manuel (Org.). Antologia de poetas brasileiros bissextos contemporâneos. Rio de Janeiro: Zélio Valverde, 1946.

BANDEIRA, Manuel (Org.). Antologia de poetas bissextos contemporâneos. 2. ed. Rio de Janeiro: Organização Simões, 1964.

CAMPOS, Paulo Mendes (Org.). Forma e expressão do soneto. Rio de Janeiro: Serviço de Documentação; Departamento de Imprensa Nacional, 1952.

CARDOZO, Joaquim. Poesia completa e prosa. Rio de Janeiro: Nova Aguilar; Recife: Massangana, 2007.

CARDOZO, Joaquim. Discurso de paraninfo (Joaquim Cardozo): Turma de Engenharia UPE (1939). In: MACEDO, Danilo; SOBREIRA, Fabiano. Forma estética/forma estática: ensaios de Joaquim Cardozo sobre arquitetura e engenharia. Brasília: Câmara dos deputados; Centro de Documentação e Informação, 2009. p. 58-61.

CORREIA, Éverton Barbosa. Joaquim Cardozo, leitor de Manuel Bandeira. In: Guavira, Três Lagoas, v. 1, n. 1, p. 61-70, 2010.

Diário Oficial do Estado de Pernambuco. Recife: DOE, 28 dez. 1939.

FREYRE, Gilberto (Org.). Livro do Nordeste. Recife: Arquivo Público Estadual, 1979.

GRÜNEWALD, José Lino (Org.). Grandes sonetos da nossa língua. Rio de Janeiro: Nova Fronteira, 1987.

HOUAISS, Antonio. Seis poetas e um problema. Rio de Janeiro: Ministério da Educação e Cultura, 1960.

MERQUIOR, José Guilherme. Uma canção de Cardozo. In: Razão do poema. Rio de Janeiro: Topbooks, 1996. p. 17-35.

PY, Fernando. Chão da crítica. Rio de Janeiro: Francisco Alves, 1984.

Recebido: $15 / 12 / 2017$

Aprovado: 05/05/2018

Contato:

Everton Barbosa Correia <evertonbcorreia@gmail.com> 